\title{
Orofaciodigital Syndrome Type 1
}

National Cancer Institute

\section{Source}

National Cancer Institute. Orofaciodigital Syndrome Type 1. NCI Thesaurus. Code C75481.

An X-linked inherited syndrome caused by mutations in the OFD1 gene mapped to chromosome Xp22.2. It is characterized by malformations of the face, oral cavity, and fingers. 